Jurnal Basicedu Volume 3 Nomor 4 Tahun 2019 Halaman 1073-1081

JURNAL BASICEDU

Research \& Learning in Elementary Education

https://jbasic.org/index.php/basicedu

\title{
PENERAPAN MODEL THINK PAIR SHARE UNTUK MENINGKATKAN KEMAMPUAN BERPIKIR KRITIS DAN HASIL BELAJAR MATEMATIKA SISWA SEKOLAH DASAR
}

\author{
Mariana Valianty ${ }^{1}$, Agustina Tyas Asri Hardini ${ }^{2}$ \\ Universitas Kristen Satya Wacana, Jawa Tengah, Indonesia ${ }^{1,2}$

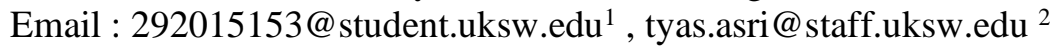

\begin{abstract}
Abstrak
Tujuan dari penelitian ini adalah untuk mendiskripsikan langkah-langkah penerapan model Think Pair Share dalam meningkatkan kemampuan berpikir kritis dan hasil belajar, mengetahui peningkatan kemampuan berpikir kritis dan mengetahui peningkatan hasil belajar. Jenis dari penelitian ini adalah penelitian tindakan kelas (PTK) yang dilakukan dua siklus. Penelitian ini dilaksanakan di SD Negeri Kutowinangun 01 Salatiga dengan subyek penelitian siswa kelas 4 SD Negeri Kutowinangun 01 total subyek 25.Teknik pengumpulan data menggunakan tehnik tes dan tehnik non tes analisi data yang digunakan adalah deskriptif kuantitatif dan kualitatif. Hasil penelitian menunjukan bahwa dengan penerapan langkah-langkah model Think Pair Share yaitu dengan berpikir (thinking) masalah yang berikan, siswa diharap berpasangan (pairing) agar mendapatkan kesepakatan jawaban dan yang terakhir yaitu berbagi (sharing) jawaban yang telah disepakati. Hal tersebut dibuktikan dari meningkatnya kemampuan berpikir kritis siswa dari kondisi pra siklus menunjukkan bahwa 20\% dengan kategori tinggi menjadi 52\% dengan kategori tinggi pada siklus I dan pada siklus II menunjukkan bahwa $84 \%$ siswa mencapai kemampuan berpikir kritis pada kategori tinggi. Peningkatan juga terjadi pada hasil belajar matematika siswa kelas 4 SD Negeri Kutowinangun 01 Kecamatan Sidorejo Lor, Salatiga semester 1 tahun ajaran 2019/2020 setelah diberikan tindakan model Think Pair Share. Sebelum tindakan sebanyak 11 siswa (44\%) yang tuntas. Setelah diberikan tindakan pada siklus I, terjadi peningkatan jumlah yang tuntas menjadi 17 siswa (68\%) pada siklus II terjadi peningkatan jumlah yang tuntas menjadi 20 (80\%).
\end{abstract}

Kata Kunci : Think Pair Share, Kemampuan Berpikir Kritis, Hasil Belajar Matematika

\begin{abstract}
The purpose of this study is to describe the steps in implementing Think Pair Share models in improving critical thinking skills and learning outcomes, learning to improve critical thinking skills and learning to improve learning outcomes. This type of research is a classroom action research (CAR) conducted two cycles. This research was conducted at SD Negeri Kutowinangun 01 Salatiga with research subjects grade 4 students of SD Negeri Kutowinangun 01 total subjects 25 . The technique of collecting data using test techniques and non-test data analysis techniques used were descriptive quantitative and qualitative. The results showed that by applying the steps of the Think Pair Share model, namely by thinking (thinking) supported problems, students are expected to pair up (pair) in order to get approval and share the results (sharing) answers that have been supported. This is evidenced from the Student Ability Policy from the pre cycle showing $20 \%$ with a high category to $52 \%$ with a high category in the first cycle and in the second cycle shows that $84 \%$ of students achieve critical thinking skills in the high category. An increase also occurred in mathematics learning outcomes of 4th grade students of SD Negeri Kutowinangun 01, Sidorejo Lor District, Salatiga in semester 1 of the 2019/2020 school year after being given the Think Pair Share model action. Before the action as many as 11 students (44\%) were completed. After being given an action in the first cycle, an increase in the number of completeness to 17 students $(68 \%)$ in the second cycle an increase in the number of completeness to $20(80 \%)$.
\end{abstract}

Key words : Think Pair Share, Critical Thinking Ability, Mathematics Learning Outcomes

@ Jurnal Basicedu Prodi PGSD FIP UPTT 2019

$\triangle$ Corresponding author :

Address :

Email :

ISSN 2580-3735 (Media Cetak)

Phone : 
1074 Penerapan model Think Pair Share untuk meningkatkan kemampuan berpikir kritis dan hasil belajar matematika siswa sekolah dasar - Mariana Valianty, Agustina Tyas Asri Hardini

\section{PENDAHULUAN}

Pembelajaran Kurikulum 2013 tidak hanya merupakan pengelompokkan dari beberapa mata pelajaran namun juga harus ada upaya pembentukan karakter siswa. Menurut Rosmaiyadi (2017:12) tujuan pembelajaran dalam Kurikulum 2013 adalah untuk mencapai High Order Thinking (HOT) kemampuan berpikir tingkat tinggi dari saat ini salah satunya yaitu berpikir kritis. Menurut Purba (2015:1) berpikir kritis adalah suatu proses kemampuan berpikir yang cukup kompleks, sehingga kemampuan berpikir siswa harus dilatih sehingga mampu berpikir dengan kritis. Menurut Permendikbud No. 21 Tahun 2016 tentang Standar Isi Pendidikan Dasar Dan Menengah dalam usaha mencapai Standar Kompetensi Lulusan sebagaimana telah ditentukan untuk setiap satuan pendidikan dan jenjang pendidikan harus mempunyai tiga ranah yaitu ranah sikap, ranah pengetahuan dan ranah keterampilan. Ranah sikap dibagi menjadi sikap spiritual dan sikap sosial. Dari pernyataan diatas, maka dapat disimpulkan bahwa kemampuan dalam berpikir tingkat tinggi berbeda pada bagian yang paling atas dalam taksonomi Bloom yang terdiri dari kemampuan dalam menganalisis, mengevaluasi, dan mencipta. Kemampuan dalam berpikir tingkat tinggi pada intinya adalah suatu pemikiran yang terjadi pada tingkat tinggi dalam suatu proses pembelajaran.

Hasil pengamatan di kelas 4 SD Negeri Kutowinangun 01 mata pelajaran Matematika, telah diperoleh bahwa masih ada siswa yang kurang mampu untuk melatih keterampilan pemecahan masalah yang dimiliki. Berdasarkan keterangan yang telah didapatkan dari guru, siswa dapat menyelesaikan soal Matematika dengan cara masih dibantu oleh guru. Siswa bisa menyelesaikan soal yang cara penyelesaiaanya memerlukan hafalan rumus Matematika. Siswa belum dapat untuk mengasah pengetahuan dan kemampuannya sendiri untuk menyelesaikan soal Matematika dalam bentuk soal cerita, proses pembelajaran yang dilaksanakan belum memakai hal yang kemampuan berpikir kritis sehingga siswa tidak dapat menyelesaikan suatu masalah dengan caranya sendiri akan tetapi masih dengan meniru contoh yang diberikan oleh guru. Perhatian siswa saat proses pembelajaran, metode atau model pembelajaran yang kurang tepat, serta keadaan lingkungan yang tidak mendukung siswa untuk menerima pelajaran,untuk itu guru harus bersikap bijaksana dalam menggunakan model yang dapat meningkatkan kemampuan memecahkan masalah dengan memberikan masalah yang meminta siswa untuk dapat berpikir secara kritis

Hasil observasi kemampuan berpikir kritis Matematika siswa dari indikator yang diamati yaitu menganalisis masalah; menentukkan konsep/cara penyelesaian; menarik kesimpulan, kemudian indikator; memberikan penjelasan lanjut; dan merumuskan cara. Tingkat kemampuan berpikir kritis Matematika dari 25 siswa didapat 5 siswa atau $20 \%$ mempunyai kemampuan berpikir kritis Matematika siswa pada kategori tinggi, sedangkan 8 siswa atau $32 \%$ memiliki kemampuan berpikir kritis Matematika siswa pada kategori sedang, sedangkan $48 \%$ atau 12 siswa memiliki kemampuan berpikir kritis Matematika siswa pada kategori sangat rendah. Hasil wawancara, didapat data bahwa beberapa siswa sulit diarahkan untuk belajar dengan fokus dan siswa kurang memperhatikan dengan materi Matematika, sehingga mendorong sikap negatif siswa di kelas saat pembelajaran berlangsung. Selain dilakukannya observasi di kelas dan wawancara terhadap guru kelas 4.

Pada saat guru meminta siswa untuk diskusi di dalam kelompok hanya ada beberapa siswa 
yang mengerjakan atau berdiskusi dan siswa lainnya masih terlihat asyik bicara sendiri dengan teman lainnya. Terlihat guru masih melakukan proses kegiatan belajar mengajar masih dengan metode ceramah, kemudian guru memberikan tugas kepada siswa dan kadang melakukan tanya jawab dengan siswa. Selain itu kemampuan siswa dalam menyelesaikan soal Matematika masih rendah. Hal tersebut dibuktikan dengan adanya hasil belajar siswa ketika ulangan harian yang belum mencapai Kriteria Ketuntasan Minimal (KKM) Matematika yaitu 70. Dari 25 siswa hanya terdapat 11 siswa atau $44 \%$, siswa yang dapat mencapai nilai KKM tersebut, dari seluruh siswa kelas 4 SD Negeri Kutowinangun 01 Kecamatan Sidorejo Lor Kota Salatiga dan 14 siswa atau 56\% siswa sebelum mencapai KKM. Dari hasil tersebut maka hasil belajar Matematika di kelas 4 SD Negeri Kutowinangun 01 masih belum mencapai tujuan yang diharapkan.

Kondisi seperti ini sebaiknya segera diatasi, baik dengan cara menindaklanjuti kerja siswa maupun model pembelajaran yang digunakan ketika proses pembelajaran Matematika berlangsung. Untuk mengatasi permasalahan tersebut diperlukan suatu model pembelajaran yang menyenangkan dan menarik bagi siswa agar tertarik dan aktif mengikuti pembelajaran.

Berdasarkan permasalahan tersebut, maka peneliti berupaya untuk menerapkan pembelajaran tersebut dengan Penelitian Tindakan Kelas (PTK) dengan judul “ Penerapan Model Think Pair Share Untuk Meningkatkan Kemampuan Berpikir Kritis dan Hasil Belajar Matematika Siswa Kelas 4 SD”. Penelitian ini bertujuan untuk mendeskripsikan peningkatan kemampuan berpikir kritis dan hasil belajar Matematika siswa kelas 4 melalui model Think Pair Share pada pembelajaran matematika di Sekolah Dasar.
Sanjaya (2012:112) belajar bukanlah hanya mengumpulkan pengetahuan. Belajar yaitu proses mental yang terjadi pada dalam diri seseorang, sehingga menimbulkan munculnya perubahan tingkah laku. aktivitas mental tersebut dapat terjadi karena adanya interaksi individu dengan lingkungannya yang disadari. Fathani (2012:19) Matematika adalah ilmu pengetahuan mengenai penalaran yang logis dan masalah yang berkaitan dengan bilangan. Matematika memiliki pengertian yaitu sebagai suatu ilmu bantu yang bisa menginterpretasikan beberapa gagasan dan kesimpulan sejalan dengan Nurhasanah (2010:1) Matematika dinyatakan abstrak karena dalam objeknya atau simbol dalam Matematika tidak ada di dalam kehidupan nyata. Siswa SD belum bisa untuk berpikir formal, maka dalam kegiatan belajar Matematika sangat diharapkan bagi banyak guru agar membuat proses belajar mengajar yang aktif dan bisa mengkaitkan kegiatan belajar mengajar dengan benda yang nyata. Selain itu, juga perlu adanya suatu proses berpikir, karena siswa tidak dapat memahami pada suatu konsep secara langsung, maka diperlukan proses mengkomunikasikannya dengan lisan atau tertulis. Jadi, dalam kegiatan pembelajaran Matematika guru harus memberikan siswa suatu kesempatan untuk dapat ikut serta berperan aktif dalam berlangsungnya proses kegiatan belajar mengajar. Jumanta (2014: 201) Think Pair Share adalah suatu teknik sederhana yang dapat memberikan keuntungan besar,dimana Think Pair Share dapat meningkatkan kemampuan siswa dalam mengingat suatu informasi dan seorang siswa juga dapat belajar dari siswa lain serta saling menyampaikan idenya untuk didiskusikan sebelum disampaikan di depan kelas. Strategi Think Pair Share berarti memberi waktu kepada siswa untuk memikirkan jawaban dari pertanyaan atau permasaahan yang diberikan oleh guru. Siswa saling membantu dalam 
1076 Penerapan model Think Pair Share untuk meningkatkan kemampuan berpikir kritis dan hasil belajar matematika siswa sekolah dasar - Mariana Valianty, Agustina Tyas Asri Hardini

menyelesaikan masalah tersebut dengan kemampuan yang dimiliki masing-masing.

Huda (2013:207) Langkah-langkah model Think Pair Share dalam pelaksanaan pembelajaran adalah sebagai berikut: a) Siswa ditempatkan dalam kelompok-kelompok. Setiap kelompok terdiri dariempat anggota/siswa; b) Guru memberikan tugas pada setiap kelompok; c) Masing-masing anggota memikirkan dan mengerjakan tugas tersebut sendiri-sendiri terlebih dahulu; d) Kelompok membentuk anggotaanggotanya secara berpasangan;e) Setiap pasangan mendiskusikan hasil pengerjaan individunya; f) Kedua pasangan lalu bertemu kembali dalam kelompoknya masing-masing untuk menshare hasil diskusinya.

Sani (2014:195) adalah sebagai berikut: a) Guru menjelaskan inti materi dan keahlian yang ingin dicapai; b) Siswa diharapkan memikirkan mengenai materi/ permasalahan yang disampaikan guru;c) Siswa diharapkan berpasangan dengan teman sebelahnya serta mengungkapkan hasil pikiran individu; d) Guru memimpin diskusi, tiap pasangan mengkomunikasikan hasil diskusi; e) dimulai aktivitas itu, guru memberikan petunjuk obrolan pada inti masalah serta memberikan lagi materi yang belum diutarakan siswa; f) Guru memberi rangkuman.

Tjokrodihardjo dalam Trianto (2013:82) tahapan pada belajar mengajar kooperatif yaitu; a) Berfikir (thinking) Guru memberikan pertanyaan atau persoalan yang dihubungkan dengan pelajaran, serta mengharapkan siswa memakai waktu dengan baik agar berpikir individu solusi dari soal yang diberikan; b) Berpasangan (pairing) Guru mengharpkan siswa untuk berpasangan dan berdiskusi jawaban yang sudah didapat. Waktu yang sudah diberikan bisa menyatukan jawaban mereka. Secara normal guru memberikan waktu tidak lebih dari 4 atau 5 menit untuk berpasangan; c) Berbagi (sharing) Pada langkah akhir, guru meminta pasangan untuk berbagi dengan temannya yang ada di kelas.

Sejalan dengan pendapat Warsono (2012:203) langkah kerja pembelajaran tipe adalah; a) Siswa duduk berpasangan;b) Guru presentasi selanjutnya memberikan pertanyaan;c) awalnya siswa diberi waktu berpikir individu;d) Siswa berbagi (share) bertukar pikiran dan pendapat dengan pasangan untuk menyelesaikan soal dari guru;e) Guru memimpin diskusi kecil, setiap kelompok mengkomunikasikan hasil diskusi;f) Guru memberikan penguatan mengenai prinsip yang harus dibahas, menambahkan pengertian dan konsep yang diluar dari perhatian siswa ketika diskusi dengan pasangan;g) Simpulan dan refleksi.

Menurut pemaparan di atas dapat diringkas tahapan pada penerapan model Think Pair Share dimulai dari berpikir (thinking) persoalan diberikan oleh guru, siswa masuk dalam kelompok pasangan (pairing) agar memperoleh kesepakatan jawaban dan yang terakhir yaitu berbagi (sharing).

Huda (2014:136-137) aturan penerapan model Think Pair Share yaitu : a) Siswa duduk dalam kelompok; b) Setiap kelompok mencakup 4 siswa; c) Guru memberikan tugas tiap kelompok; d) tiap anggota berpikir serta mengerjakan tugas tersebut sendiri dulu; e) Kelompok membentuk anggotanya berpasangan; f) tiap pasangan berdiskusi hasil pengerjaan individu; g) Kedua pasangan bertemu lagi pada tiap kelompk guna mengkomunikasikan hasil diskusinya. Menurut pengertian di atas dapat diringkas tahap dalam penerapan model Think Pair Share ini dimulai dengan berpikir (thinking) soal yang diberikan guru, siswa berpasangan (pairing) untuk memperoleh kesepakatan jawaban dan berbagi (sharing) jawaban yang telah disepakati.

Ahmatika (2015:395) berpikir kritis yaitu kemampuan berpikir kritis ialah kemampuan yang sangat esensial, yang memiliki fungsi efektif pada tiap aspek kehidupan. Maka, kemampuan berpikir 
1077 Penerapan model Think Pair Share untuk meningkatkan kemampuan berpikir kritis dan hasil belajar matematika siswa sekolah dasar - Mariana Valianty, Agustina Tyas Asri Hardini

kritis menjadi sangat penting fungsinya dan harus ditanamkan sejak dini baik di sekolah, di rumah atau di masyarakat. Pada tahap terlaksananya belajar mengajar guna memperoleh hasil yang maksimal diperlukan berpikir dengan aktif. Menurut Santrock (2011:359) berpikir kritis yaitu pemikiran produktif yang mengkaitkan evaluasi bukti. Cece Wijaya (2010:72) kemampuan berpikir kritis, ialah proses menelaah ide atau gagasan ke arah yang lebih spesifik, membedakannya secara tajam,

Ennis dalam Rosnawati, (2012:6) indikator kemampuan berpikir kritis dipilah 5 kelompok meliputi:1) memberikan pengertian sederhana; 2) membentuk kemampuan dasar; 3) menyimpulkan; 4) membuat pengertian lebih lanjut dan menyusun rencana dan taktik; 5) kemampuan kelima kelompok berpikir kritis ini dipecah lagi menjadi; a). Memberikan pengertian sederhana mencakup kemampuan dalam memusatkan pertanyaan, menelaah argumen, bertanya serta menjawab pertanyaan; b) membentuk kemampuan dasar yang meliputi menyamakan dengan sumber, mengobservasi serta mengkomunikasikan hasil pengamatan; c). meringkas mencakup kemampuan memikirkan kesimpulan, menyamaratakan serta melaksanakan penilaian; d). Membuat penjelasan lanjut misalnya mendefinisikan istilah serta membikin pengertian; e). Memerintah rencana serta taktik misalnya dengan memilih tindakan dan berhubungan dengan orang lain serta berkomunikasi.

\section{METODE}

Subjek dalam penelitian ini adalah siswa kelas 4 SD Negeri Kutowinangun 01 yang berjumlah 25 siswa yang terdiri dari 11 siswa lakilaki dan 14 siswa perempuan. Penelitian ini memakai jenis Penelitian Tindakan Kelas (PTK). Penelitian ini memakai penelitian kolaboratif, berlangsungnya penelitian ini bisa dengan bekerja sama dengan guru kelas 4 SD Negeri Kutowinangun 01. Instrumen penelitian siklus I total ada 10 soal isian dan siklus II total ada 10 soal esay yang telah diuji validitasnya dengan memakai Anates Ver. 4.0.9,

Instrumen soal yang dipakai guna menguji hasil belajar siswa serta menguji kemampuan berpikir kritis siswa digunakan instrumen berupa angket kemampuan berpikir kritis. Ennis dalam Rosnawati, (2012:6) indikator kemampuan berpikir kritis ada lima kelompok yaitu; a) memberikan penjelasan sederhana; b) memunculkan kemampuan dasar; c) menyimpulkan; d) menyusun penjelasan lebih lanjut; e) mengatur strategi dan taktik.

Pada penelitian ini ada lembar pengamatan aktivitas guru serta lembar pengamatan aktivitas siswa, isi dari lembar pengamatan yaitu tentang inti dari berlangsungnya belajar mengajar yang dirancang sama seperti langkah dalam penerapan model Think Pair Share. Penelitian ini memakai teknik analisa data deskriptif komparatif, yang menimbang-nimbang nilai tes pra siklus, sesudah dilakukannya siklus I dan siklus II untuk memperoleh informasi perkembangan kemampuan berpikir kritis serta hasil belajar siswa tiap siklus. Penelitian tindakan kelas ini dilakukan di dua siklus memakai model C.Kemmis dan C.Taggart, $\mathrm{R}$ dimana di setiap siklusnya ada empat tahap yakni tahap merencanakan, melaksanakan, mengobservasi, dan refleksi.

Langkah di pembelajaran siklus I ialah : 1) Perencanaan, aktivitas yang dilaksanakan yaitu penyusunan Rencana Pelaksanaan Pembelajaran yang sama dengan model Think Pair Share, menyiapkan suatu media pembelajaran, penyusunan lembar observasi aktivitas guru dan siswa serta penyusunan lembar soal. 2) Pelaksanaan, yaitu tahapan berlangsungnya aktivitas belajar mengajar sama dengan rencana pelaksanaan pembelajaran yang sudah dirancang. 3) Pengamatan, langkah ini dilakukan saat proses 
1078 Penerapan model Think Pair Share untuk meningkatkan kemampuan berpikir kritis dan hasil belajar matematika siswa sekolah dasar - Mariana Valianty, Agustina Tyas Asri Hardini

belajar mengajar terjadi, serta menggunakan apa yang ada disekitar siswa. 4) Refleksi, langkah ini adalah suatu tahapan untuk menelaah kesuksesan dan kesukaran pada proses belajar siklus I agar bisa ditingkatkan di siklus berikutnya. Tindakan yang ada di siklus II langkah yang dilakukan sama seperti di pembelajaran siklus I, tetapi tindakan yang dilakukan di pembelajaran siklus II adalah upaya tindakan untuk melengkapi kesalahan yang terjadi di pembelajaran siklus I, agar proses belajar mengajar di siklus II mendapatkan hasil yang meningkat dari siklus I serta hasil yang didapat selaras yang diharapkan ialah meningkatnya kemampuan berpikir kritis serta hasil belajar yang didapatkan siswa. Teknik untuk mengumpulkan data di penelitian ini yaitu dengan cara tes dan nontes. Teknik tes ini merupakan memberikan soal berbentuk isian guna menguji keterampilan belajar siswa di masing-masing siklus. Teknik nontes yang digunakan pengamatan yang dilakukan ketika kegiatan belajar mengajar terlaksana dengan memakai lembar pengamatan kegiatan aktivitas guru dan lembar pengamatan siswa agar memperoleh informasi mengenai aktifitas siswa serta guru saat proses pembelajaran berlangsung dan angket kemampuan berpikir kritis agar mendapatkan data tentang kemampuan berpikir kritis siswa. Indikator keberhasilan pada penelitian ini adalah meningkatnya kemampuan berpikir kritis dan hasil belajar Matematika siswa kelas kelas 4 SD Negeri Kutowinangun 01. Siswa dikatakan tuntas belajar jika nilai rata-rata siswa keseluruhan dalam pembelajaran Matematika mengalami peningkatan sebanyak $80 \%$ siswa mendapat nilai $\geq 70$ dengan KKM 70. Pembelajaran dengan menerapkan model Think Pair Share dikatakan berhasil apabila dengan menggunakan model tersebut dapat meningkatkan hasil belajar siswa kelas $4 \mathrm{SD}$ Negeri Kutowinangun 01.

\section{HASIL DAN PEMBAHASAN}

Kemampuan berpikir kritis siswa dengan menerapkan model Think Pair Share selama proses pembelajaran Matematika materi mencari KPK dan FPB dari dua bilangan pada setiap siklusnya menunjukkan bahwa adanya peningkatan. Langkah awal untuk mengetahui kemampuan berpikir kritis siswa dilakukan pada pra siklus dalam upaya untuk mengetahui tindakan yang akan diberikan. Selanjutnya, dilakukan pembelajaran siklus I dan siklus II untuk mengetahui pencapaian siswa selama menggunakan model Think Pair Share. Berikut ini merupakan tabel 1 peningkatan kemampuan berpikir kritis siswa dari pra siklus, siklus I sampai siklus II.

\section{Tabel 1 Perbandingan Hasil Data Kemampuan Berpikir Kritis Siswa}

\begin{tabular}{|c|c|c|c|c|c|c|c|}
\hline \multirow[t]{2}{*}{$\begin{array}{l}\text { Rentang } \\
\text { Skor }\end{array}$} & \multirow{2}{*}{$\begin{array}{l}\text { Kategori } \\
\text { Kemampu } \\
\text { an } \\
\text { Berpikir } \\
\text { Kritis }\end{array}$} & \multicolumn{2}{|c|}{$\begin{array}{l}\text { Pra } \\
\text { Siklus }\end{array}$} & \multicolumn{2}{|c|}{$\begin{array}{l}\text { Siklus } \\
\text { I }\end{array}$} & \multicolumn{2}{|c|}{$\begin{array}{l}\text { Siklus } \\
\text { II }\end{array}$} \\
\hline & & $\begin{array}{l}\text { Ju } \\
\text { mla } \\
\text { h }\end{array}$ & $\%$ & $\begin{array}{l}\mathbf{J} \\
\mathbf{u} \\
\mathbf{m} \\
\mathbf{l a} \\
\mathbf{h}\end{array}$ & $\%$ & $\begin{array}{l}\mathbf{J} \\
\mathbf{u} \\
\mathbf{m} \\
\mathbf{l a} \\
\mathbf{h}\end{array}$ & $\%$ \\
\hline $60-80$ & Tinggi & 5 & $\begin{array}{l}2 \\
0\end{array}$ & $\begin{array}{l}1 \\
3\end{array}$ & $\begin{array}{l}5 \\
2\end{array}$ & 21 & $\begin{array}{l}8 \\
4\end{array}$ \\
\hline $30-59$ & Sedang & 8 & $\begin{array}{l}3 \\
2\end{array}$ & 7 & $\begin{array}{l}2 \\
8\end{array}$ & 4 & $\begin{array}{l}1 \\
6\end{array}$ \\
\hline $0-29$ & Rendah & 12 & $\begin{array}{l}4 \\
8\end{array}$ & 5 & $\begin{array}{l}2 \\
0\end{array}$ & 0 & 0 \\
\hline Jumlah & & 25 & $\begin{array}{l}10 \\
0\end{array}$ & 25 & $\begin{array}{l}1 \\
0 \\
0\end{array}$ & 25 & $\begin{array}{l}10 \\
0\end{array}$ \\
\hline
\end{tabular}

Keterangan:

$\mathrm{F}=$ Frekuensi/banyaknya siswa

$\%=$ kemampuan berpikir kritis

Dari tabel 1 diatas, dapat diketahui bahwa dari data pra siklus sampai pelaksanaan siklus II terjadi peningkatan pada kemampuan berpikir kritis siswa. Pada pra siklus, siswa yang berada dalam kategori tinggi sebanyak 5 siswa atau $20 \%$ dari jumlah siswa sekelas yaitu 25 siswa. Kemudian setelah dilakukan siklus I, siswa yang berada pada kategori tinggi menjadi 13 siswa atau 
1079 Penerapan model Think Pair Share untuk meningkatkan kemampuan berpikir kritis dan hasil belajar matematika siswa sekolah dasar-Mariana Valianty, Agustina Tyas Asri Hardini

$52 \%$ selanjutnya meningkat menjadi 21 siswa atau 84\%. Persentase ini meningkat kembali pada siklus II sebesar 34\% sehingga didapati siswa yang berada dalam kategori tinggi sebanyak siswa dengan persentase sebesar 84\%. Selanjutnya siswa yang berada dalam kategori sedang pada pra siklus menunjukkan persentase sebesar 32\% atau 8 siswa dalam kategori sedang. Setelah dilakukan siklus I, persentase ini menurun sebesar $4 \%$ atau 7 siswa dalam kategori sedang sehingga persentasenya menjadi $28 \%$. Kemudian, siswa yang berada dalam kategori rendah yang ditunjukkan pada pra siklus menunjukkan persentase yaitu $48 \%$ dengan jumlah 12 siswa. Setelah dilakukan siklus I, persentase ini menurun sebesar $28 \%$ atau 7 siswa dalam kategori sedang. Kemudian kategori rendah menurun menjadi 7 siswa dengan persentase sebesar $28 \%$. Setelah dilakukan siklus II jumlah siswa dalam kategori rendah menurun menjadi 0 siswa dengan persentase sebesar $0 \%$. Hasil ini terus menunjukkan perubahan yang baik, dimana pada siklus II sudah tidak ada siswa yang berada dalam kategori rendah pada kemampuan berpikir kritis.

Berdasarkan hasil penelitian yang telah dilakukan menggunakan model Think Pair Share pada mata pelajaran Matematika terjadi peningkatan hasil belajar siswa. Peningkatan tersebut dapat dilihat pada perbandingan nilai pra siklus, siklus I dan siklus II tabel 2 berikut:
Tabel 2 Perbandingan Hasil Belajar Matematika Pra Siklus, Siklus I dan Siklus II

\begin{tabular}{|c|c|c|c|c|c|c|c|c|}
\hline \multirow[t]{2}{*}{$\begin{array}{l}\mathbf{N} \\
\mathbf{0}\end{array}$} & \multirow{2}{*}{$\begin{array}{l}\text { Nilai } \\
\text { KKM } \\
\geq 70\end{array}$} & \multirow[t]{2}{*}{$\begin{array}{l}\text { Kriter } \\
\text { ia }\end{array}$} & \multicolumn{2}{|c|}{$\begin{array}{l}\text { Pra } \\
\text { Siklus }\end{array}$} & \multicolumn{2}{|c|}{ Siklus I } & \multicolumn{2}{|c|}{ Siklus II } \\
\hline & & & $\begin{array}{l}\text { Ju } \\
\text { ml } \\
\text { ah }\end{array}$ & $\%$ & $\begin{array}{l}\text { Ju } \\
\text { ml } \\
\text { ah }\end{array}$ & $\%$ & $\begin{array}{l}\text { Ju } \\
\text { ml } \\
\text { ah }\end{array}$ & $\%$ \\
\hline 1 & $\geq 70$ & Tuntas & 11 & 44 & 17 & 68 & 20 & 80 \\
\hline 2 & $<70$ & $\begin{array}{l}\text { Tidak } \\
\text { Tuntas }\end{array}$ & 14 & 56 & 8 & 32 & 5 & 20 \\
\hline \multicolumn{3}{|c|}{ Jumlah } & 25 & 100 & 25 & 100 & 25 & 100 \\
\hline \multicolumn{3}{|c|}{ Nilai Tertinggi } & \multicolumn{2}{|l|}{70} & \multicolumn{2}{|l|}{80} & \multicolumn{2}{|l|}{90} \\
\hline \multicolumn{3}{|c|}{ Nilai Terendah } & \multicolumn{2}{|l|}{20} & \multicolumn{2}{|l|}{36} & \multicolumn{2}{|l|}{60} \\
\hline \multicolumn{3}{|c|}{ Nilai Rata-Rata } & \multicolumn{2}{|l|}{54} & \multicolumn{2}{|l|}{65} & \multicolumn{2}{|l|}{76} \\
\hline
\end{tabular}

Tabel 2 dapat dilihat adanya peningkatan jumlah ketuntasan hasil belajar siswa. Yang awalnya pada pra siklus sebelum diadakannya tindakan, ketuntasan siswa hanya mencapai $44 \%$, setelah digunakan model Think Pair Share meningkatkan menjadi $68 \%$ kemudian setelah tindakan dilakukan dalam II siklus hasil belajar siswa meningkat lagi mencapai $80 \%$ dari jumlah keseluruhan siswa. peningkatan nilai tertinggi dan nilai terendah pada setiap siklus selalu meningkat. Pada pra siklus nilai tertinggi 70 dan nilai terendah 20 dan nilai rata-rata 54, setelah dilakukan tindakan pada siklus I nilai tertinggi 80 dan nilai terendah 36 dan nilai rata-rata 65 , dari pembelajaran siklus II nilai tertinggi siswa 90 dan nilai terendah siswa adalah 60 serta nilai rata-rata siklus II yaitu 76 .

Dari hasil pemaparan, dapat diperoleh kesimpulan bahwa penerapan model Think Pair Share yang telah dilakukan dapat dikatakan berhasil. Pembelajaran dengan model pembelajaran ini dapat membuat siswa menjadi lebih aktif dan kreatif dalam proses pembelajaran. Siswa dituntut untuk bisa berpikir lebih dan terpacu dalam berkompetisi dengan siswa yang lain, sehingga tidak bosan dalam mengikuti pembelajaran. Hal ini yang menjadikan hasil 
1080 Penerapan model Think Pair Share untuk meningkatkan kemampuan berpikir kritis dan hasil belajar matematika siswa sekolah dasar - Mariana Valianty, Agustina Tyas Asri Hardini

belajar Matematika siswa di kelas 4 SD Negeri

Kutowinangun 01 Kecamatan Sidorejo Lor, Kota Salatiga pada materi KPK dan FPB menjadi meningkat. Hal ini juga sejalan dengan pernyataan teoritis tentang model Think Pair Share menurut Shoimin (2014:208) Model Think Pair Share merupakan suatu model pembelajaran kooperatif yang memberi siswa waktu untuk berpikir dan merespon serta saling bantu satu sama lain. Disamping itu, model pembelajaran Think Pair Share dapat menciptakan suasana belajar siswa dengan berbagi ide bersama teman pasangannya secara nyaman.

\section{SIMPULAN}

Berdasarkan hasil temuan dan pembahasan yang telah dipaparkan dapat disimpulkan bahwa penggunaan model Think Pair Share telah berhasil meningkatkan kemampuan berpikir kritis dan hasil belajar Matematika pada siswa kelas $4 \mathrm{SD}$ Negeri Kutowinangun 01 semester I Tahun 2019/2020. Hal ini ditunjukkan dengan perbandingan kemampuan berpikir kritis siswa pra siklus, siswa yang berada dalam kategori tinggi sebanyak 5 siswa atau $20 \%$ dari jumlah siswa. Kemudian setelah dilakukan siklus I, siswa yang berada pada kategori tinggi meningkat menjadi 13 siswa atau 52\% selanjutnya meningkat menjadi 21 siswa atau 84\%. pada siklus II. Selanjutnya siswa yang berada dalam kategori sedang pada pra siklus menunjukkan persentase sebesar $32 \%$ atau 8 siswa dalam kategori sedang. Setelah dilakukan siklus I, persentase ini menurun sebesar $28 \%$ atau 7 siswa dalam kategori sedang. Kemudian siswa yang berada dalam kategori rendah yang ditunjukkan pada pra siklus menunjukkan persentase yaitu $48 \%$ dengan jumlah 12 siswa. Setelah dilakukan siklus I, persentase ini menurun sebesar $52 \%$ atau 16 siswa dalam kategori sedang. Setelah dilakukan siklus II jumlah siswa dalam kategori rendah menurun menjadi 0 siswa dengan persentase sebesar 0\%. Hasil ini terus menunjukkan perubahan yang baik, dimana pada siklus II sudah tidak ada lagi siswa yang berada dalam kategori rendah pada kemampuan berpikir kritis. Hasil belajar Matematika berdasarkan ketuntasan belajar dengan $\mathrm{KKM} \geq 70$ diketahui bahwa hasil analisis dari 25 siswa yang tuntas sebelum tindakan adalah 11 siswa (44\%). Setelah diberikan tindakan pada siklus I terjadi peningkatan jumlah ketuntasan siswa menjadi 17 siswa (68\%). Setelah diberikan tindakan pada siklus II, terjadi lagi peningkatan jumlah ketuntasan menjadi 20 siswa $(80 \%)$. siswa yang belum tuntas sebelum diberikan tindakan adalah 14 siswa (56\%). Setelah diberikan tindakan pada siklus I, berkurang menjadi 8 siswa (32\%). Setelah dilaksanakan lagi tindakan pada siklus II, menjadi 5 siswa $(20 \%)$ yang belum tuntas

\section{DAFTAR PUSTAKA}

Ahmatika, Deti. 2015. "Peningkatan Kemampuan Berpikir Kritis Siswa Dengan Pendekatan Inquiry/Discovery", Jurnal Euclid. Vol.1 No. 3, hlm 394403.

Cece Wijaya.2010. Pendidikan Remidial: Sarana Pengembangan Mutu Sumber Daya Manusia. Bandung: PT Remaja Rosdakarya.

Fathani, Matematika Hakikat dan Logika, (Yogyakarta: Ar Ruzz Media, 2012), hal. 19

Hamdayama, Jumanta. 2014. Model Pebelajaran Kreatif dan Berkarakter. Bogor: Ghalia Indonesia.

Huda,Miftahul.2013.Model-Model Pengajaran dan Pembelajaran.Yogyakarta: Penerbit Pustaka Pelajar.

Miftahul Huda.2014.Cooperative Learning: Metode, Teknik, Struktur dan Model Penerapan. Yogyakarta: Pustaka Pelajar 
1081 Penerapan model Think Pair Share untuk meningkatkan kemampuan berpikir kritis dan hasil belajar matematika siswa sekolah dasar - Mariana Valianty, Agustina Tyas Asri Hardini

Nurhasanah, F.2010. Abstraksi Siswa SMP dalam Belajar Geometri melalui Penerapan Model Van Hiele dan Geomeer's Sketchpad. Tesis Magister SPs UPI Bandung: Tidak diterbitkan.

Permendikbud.2014.Peraturan Menteri Pendidikan dan Kebudayaan Republik IndonesiaNomor 57 Tahun 2014 Tentang Kurikulum 2013 Sekolah Dasar/Madrasah Ibtidaiyah

Permendiknas No 23 Tahun 2016. Tentang Standar Kompetensi Lulusan Untuk Satuan Pendidikan Dasar dan Menengah. Jakarta: Depdiknas

Purba, R. T. 2015. Sebuah Tinjauan Mengenai Stimulus Berpikir Kritis bagi Siswa Sekolah Dasar. Jurnal Pendidikan dan Kebudayaan,5 (3), 59-64.

Rosmaiyadi,

$\mathrm{R}$.

2017.Analisis

KemampuanBerpikir Kritis

Matematis Siswa Dalam Learning Cycle7e Berdasarkan Gaya Belajar. Jurnal Aksioma,6 (1),12-19.

Rosnawati, R.2012. Berpikir Kritis Melalui Pembelajaran Matematika Untuk Mendukung Pembentukan Karakter Siswa. In Makalah. Disampaikan dalam Seminar Nasional Pendidikan di Universitas Sanada Dharma.

Sani, Ridwan Abdullah. 2014. Pembelajaran Saintifik untuk Implementasi Kurikulum 2013. Jakarta: Bumi Aksara.

Sanjaya,W.,2012, Strategi Pembelajaran Berorientasi Standar Proses Pendidikan, Kencana, Jakarta.

Santrock, John W.2011. Perkembangan Anak Edisi 7 Jilid 2. (Terjemahan: Sarah Genis B) Jakarta: Erlangga

Shoimin, A., 2014. Model Pembelajaran Inovatif dalam Kurikulum 2013. Yogyakarta: Ar-Ruz Media.

Trianto.2013. Mendesain Model Pembelajaran Inovatif, Progresif, Konsep, Landasan, dan Implementasinya Pada Kurikulum Tingkat Satuan Pendidikan (KTSP). Jakarta: Kencana Prenada Media Group

Warsono dan Hariyanto. 2012. Pembelajaran Aktif Teori dan Asesmen. Bandung: PT Remaja Rosdakarya 